\title{
Migration, marital arrangements and consumption smoothing among Burkinabè farm households
}

\author{
Pam Zahonogo \\ Université Ouaga II, Burkina Faso, 03 BP 7164 Ouagadougou 03 Burkina Faso.
}

Received 25 September, 2015 ; Accepted 3 February, 2016

\begin{abstract}
Risk coping is a severe challenge for households in developing countries, particularly for farm household because income is stochastically variable and credit markets are incomplete. Because of lack of formal systems to cope with risk, households rely on informal arrangements such as migration and marriage. This paper contributes to the literature of risk-coping strategies by examining how migration and marital arrangements serve to mitigate income risk and facilitate consumption smoothing in rural Burkina Faso, a low-income country characterized by rainfall variability in conjunction with very low income levels and a pressing need for consumption-insurance. The findings suggest that households cannot smooth consumption via assets transactions because markets work imperfectly. Households rely on self insurance arrangements to smooth consumption through inherited wealth, marriage and migration.
\end{abstract}

Key words: Consumption smoothing, risk sharing, marital arrangements, migration.

\section{INTRODUCTION}

In low-income economies, many markets do not exist and, of those that do, many work imperfectly. In this case, agricultural populations are characterized by the linkage between production and consumption decisions (Benjamin, 1992). In particular, almost all the assets held by farmers contribute directly to production and can also serve to smooth consumption when income is stochastically variable and credit markets are incomplete. Attanasio and Pavoni (2011) argue that perfect risk sharing is not achieved because of asymmetries of information. As in many developing countries, a large fraction of Burkinabè households depend on highly seasonal agriculture for their income and operate in risk environment. Rural households in developing countries frequently experience economic hardships, but often they have little social protection (Park, 2006). The potential demand for insurance and credit is high in most lowincome economies not only average incomes are low, but also they tend to be volatile, largely due to important role played by agriculture (Morduch, 1995). Rainfall variability and fluctuations in commodities prices translate to income shocks for farm households. Poor agrarian households face borrowing constraints that make it difficult for them to smooth consumption across seasons (Paxson, 1993). Households are also faced to risk from business failures, recessions and illness. Thus coping

*Corresponding author. E-mail: pzahonogo@gmail.com. Tel. +226702681 13 or +22678241124.

JEL Classification: D12, J12, J61, 130

Author(s) agree that this article remain permanently open access under the terms of the Creative Commons Attribution 
with risk is a great challenge for households in developing countries, particularly for farm households. In the absence of formal financial institutions, a large range of nonmarket solutions has become available to insure households against a negative shock and to allow them to smooth consumption over time (Hoogeveen et al., 2011). How rural households cope with hardships and smooth out consumption have been extensively studied (Park, 2006). There have been a relevant works dealing with informal risk-sharing and consumption smoothing arrangements (Alderman and Paxon, 1994; Fafchamps and Lund, 2003; Townsend, 1994; Rosenzweig and Stark, 1989; Kazianga and Udry, 2006; Kaplan and Violante, 2010). These studies conclude that most households succeed in protecting their consumption from the full effect of the income shocks to which they are subject, but not perfectly.

Risk-coping strategies involve risk mitigation through production and employment decisions. Coping with risk can occur at two stages: (i) households can smooth income by making conservative production and employment choices, diversifying economic activities to protect themselves from adverse income shocks before they occur and (ii) households can smooth consumption by borrowing and saving, depleting and accumulating non financial assets, adjusting labor supply, and employing formal and informal insurance arrangements (Udry, 1994; Kochar, 1999; Fafchamps and Lund, 2003; Park, 2006). These mechanisms take place after shocks' occurrence and help to insulate consumption patterns from income variability. The nonexistence of competitively provided crop insurance and the difficulties of credit provision in most low-income rural areas are in part consequences of the spatial character of agricultural risks. Protection against risks, however, is an important need for households engaged in agricultural production (Rosenzweig and Stark, 1989).

Because of lack of formal systems to cope with risk, households rely to informal arrangements, and migration and marriage are such arrangements. Migrant remittances can serve as insurance and help to smooth consumption (Yang and Choi, 2007; Yang, 2008, 2011; Bradford, 2013). Marriage across villages, whereby one of the marital partners migrates to the household of the other partner, thus is part fulfills the role of an institution providing income insurance benefits for households in the presence of spatially covariant risks (Rosenzweig and Stark, 1989). One strategy, by which a household may spatially diversify its sources of income, using the bonds of kinship to mitigate the consequences of enforcement costs, is to locate its members in areas characterized by low covariances in income.

This paper examines how migration and marital arrangements among households are manifestations of implicit contractual arrangements serving to mitigate income risk and facilitate consumption smoothing in rural Burkina Faso. Inter-household migration is frequent in
Burkina Faso. About $39 \%$ of rural households surveyed in 1994 and $42 \%$ of those surveyed in 1998 report some migration activity. Migration contributed through transfers on average to $36 \%$ and to $19 \%$ in rural households income in 1994 and 1998, respectively (INSD, 1998). Using ICRISAT data, Zahonogo (2002) found that transfers from migration contribute up to $22 \%$ of household's income in the drought-prone zones of Burkina Faso. Burkina Faso offers an interesting setting for examining migration and marital arrangements. Formal institutions are very limited, and private arrangements to smooth consumption are believed to be important (Kazianga, 2006). In Burkina Faso like in most developing countries, there are informational costs and spatially risks due to rainfall variability and social security institutions are not performed. Particularly, in rural areas, rainfall variability in conjunction with very low and seasonal income levels creates a pressing need for consumptioninsurance. People who live in the rural areas often must cope not only with severe poverty but also with extremely variable and seasonality incomes. Because of lack of formal system, the consumption-insurance relies on informal arrangements and inter-household migration and marital arrangements are central elements of these social arrangements. Rural households in poor developing countries are typically ill-equipped to cope with large shocks. Formal insurance schemes are mostly absent and informal risk-sharing arrangements and savings offer only partial consumption smoothing (Morduch, 1995; Townsend, 1995; Blundell at al., 2008).

Few studies from economists on inter-household migration and marital arrangements in Burkina Faso exist. In Burkina Faso, households are faced with several risks: rainfall, natural disasters, predator invasions, and the volatility of the prices of farm products. These risks lead to fluctuations in agricultural income and households' exposure to consumption shocks. Faced with these risks, the alternatives for farmers are few. Insurance is precluded because of high geographic covariance of risk, high moral hazard, and high geographic dispersion of production, that is, a given area accounts for only a very small part of total production in most parts of the country, with some possible exceptions for the cotton zones. Credit is limited due to a lack of collateral: land has little value and livestock is an uncertain stock, as it can be either stolen or exterminated by disease. Credit is also limited by the paucity of lending institutions more or less suited to this type of situation. Savadogo et al. (2006) found that only $42 \%$ of rural households in Burkina Faso have access to credits and $19 \%$ of those credits were from informal sector. Because of the failure of these common mechanisms to cope with risk, farmers rely on agent-level mechanisms, diversification, and asset accumulation for consumption smoothing, and on societybased insurance arrangements.

Social networks play an important role in responding to risk. In Burkina Faso, Transfers of income from urban 
areas or outside the country to rural areas are important, comprising up to $22 \%$ of household income in the drought-prone zones of Burkina Faso (Zahonogo, 2002). Asset accumulation, for consumption smoothing in the form of livestock or in other forms, are also reported in field studies. The risk management response mechanisms put in place may have detrimental impacts on growth however. Zahonogo (2002) found that income transfer from migration can help households smoothing consumption. Kazianga and Udry (2006) find evidence of little consumption smoothing in rural Burkina Faso. Their study did not consider mobility and marital arrangements for consumption smoothing. Their results suggest that there is no risk sharing and households rely almost on self-insurance in the form of adjustments to grains stocks to smooth consumption.

This paper uses panel data from the Deuxième Programme National de Gestion des Terroirs (PNGT2) survey for 2004 to 2006. Using detailed information on the socioeconomic status of households provided by the data, the contribution of marriage and migration, as well as of inherited wealth, to consumption smoothing in rural Burkina Faso were estimated directly. The main findings of this research can be summarized as follows. In rural Burkina Faso, households cannot smooth consumption via assets transactions because markets work imperfectly. Thus, they rely on self-insurance arrangements to smooth consumption through inherited wealth, marriage and migration.

The remainder of the paper is organized as follows. Section 2 discusses various consumption smoothing strategies suggested by the previous literature. Section 3 presents the empirical strategies. Section 4 presents the data. Section 5 analyzes the empirical results. Section 6 concludes the paper.

\section{CONSUMPTION SMOOTHING IN LOW-INCOME COUNTRIES}

The economic theory of fully functioning market suggests that household is not vulnerable to income shocks, because all risk should be diversified away so that idiosyncratic or transitory shocks should have no impact on consumption levels. If there are complete markets for credit, transitory income shocks should be smoothed away by borrowing and saving and should not affect consumption patterns (Morduch, 1995). Previous studies found that consumption smoothing is real and significant in low income economies, but is not complete (Morduch, 1995; Townsend, 1994). Yang (2011) argues that there exist two strands of research on consumption and risk sharing: (i) one studies those informal insurance networks that might serve as a substitute for social or marketpurchased insurance and (ii) the other measures that households take to overcome economic hardships, either by themselves or with help from others. The first strand of research examines various dimensions along which informal insurance networks of households may be formed and investigates how efficiently a network functions as insurance (Townsend, 1994; Grimard, 1997; Goldstein, 1999; Fafchamps and Lund, 2003; Witoelar, 2005). These authors generally find that such networks help household smooth their consumption. Most studies reject the hypothesis that risks are pooled with village networks (Townsend, 1994; Udry, 1994; Jalan and Ravallion, 1999; Gertler and Gruber, 2002). Grimard (1997) rejects complete risk sharing among households within an ethnic group in Côte d'Ivoire while Witoelar (2005) do so between extended families in Bangladesh and Indonesia.

When markets for consumption smoothing failed, risk aversion may affect how households decide both the composition and the nature of income generating activities. One method for households to smooth income is to favor variability reducing inputs and production techniques (Morduch, 1995). In South India, rice farmers have been shown to use more labor than would be called for on the grounds of profit maximization alone and inputs may be used less intensively as a way of reducing the level of investment tied up in risky activities (Antle, 1987). Bliss and Stern (1982) found that farmers could substantially raise expected profits by increasing application of fertilizer, but by using less fertilizer, investment losses are reduced in bad times. So the foregone expected profits are most plausibly explained by high levels of risk and risk aversion. Binswanger and Rosenzweig (1993) estimate that as the environment becomes riskier, vulnerable households would be expected to shift production into conservative, but less profitable modes.

The importance of rainfall suggests that it can be wise for households to post pone making investment until they have better information on expected weather conditions (Morduch, 1995). If it is known that weather will be poor, households may choose to limit production to avoid potential losses, resulting in the fact that the variability of area cultivated has been found to be higher than yield variability in India (Walker and Ryan, 1990). While it may help to smooth income, this strategy can be costly. For example, Bliss and Stern (1982) estimate that in Palanpur region of India, delaying the onset of production by two weeks can reduce yields by $20 \%$. Similar types of tradeoffs are found in the investigation of sequential aspects of uncertainty and labor supply in Burkina Faso by Fafchamps (1993).

One of the most important strategies for coping with risk is diversification activities. There are two important kinds of activities diversification: diversification of farm activities and diversification in off-farm activities. Morduch (1990) found that households whose consumption levels are most vulnerable to income shocks devote a greater share of land to safer, traditional varieties of rice and castor than to riskier, high-yielding varieties. The most 
vulnerable households are more likely to diversify plots, a common means to reduce the impact of weather shocks that vary with location. Another kind of income diversification involves off-farm activities. Rosenzweig and Stark (1989) found that households facing greater volatility in farm profits are also more likely to have a household member employed in steady wage employment. In rural India, household males tend to increase their market hours of work in response to unanticipated variations in crop profits (Kochar, 1999). According to Ellis (2000), households diversify their activities to smooth income and consumption in developing countries as coping strategies and this contribute to rural poverty reduction. Paxson (1992) found in the case of Thailand that seasonal consumption patterns are the result of the seasonal variations in preferences or prices common to all households, rather than an inability of households to use saving behavior to smooth consumption. When insurance markets are incomplete, saving and credit transactions assume a special role by allowing households to smooth their consumption streams in the face of random income fluctuations (Udry, 1995). Udry (1994) finds that households in Northern Nigeria get loans in time of need, which they repay depending on realization of random shocks to themselves and lenders. In contrast to the study by Rosenzweig and Wolpin (1993), Fafchamps et al. (1998) found no evidence that livestock is used as a buffer stock in West Africa. Fafchamps and Lund (2003) indicate that, in rural Philippines, gifts and interest-free loans from friends and families are the principal means of consumption smoothing while crop and livestock sales or labor supply play a little role.

Marriage contributes to a reduction in the variability of household consumption in India (Rosenzweig and Stark, 1989). In Zimbabwe, Hoogeveen et al. (2011) found that households use unmarried daughters as assets that can be cashed during times of adversity to smooth consumption. Their findings suggest that the marriage rate for daughters from poor households is higher and particularly after a negative shock to livestock wealth, the marriage rate of daughters increases. Marriage may act as nonmarket insurance and should be considered as a contract between families rather between individuals. Through marriage, families related share resources in an effort to deal with risks by marrying into different families (Hoogeveen et al., 2011). Marriages over long distance or with someone with job in town are considered with favor as these mitigate the impact of local weather shocks (Rosenzweig and Stark, 1989).

\section{THEORETICAL MODEL}

Framework developed by Rosenzweig and Stark (1989) was used to analyze the influence of migration and marital arrangements on a household's ability to smooth its consumption when faced with highly variable income streams. Consider a household that produces in each year $t$, a stochastic income $\pi_{t}$ from crop production. For household $\mathrm{h}$ in year $\mathrm{t}$ consumption $C_{h t}$ is then:

$C_{h t}=\pi_{h t}+\delta_{h t}$

where $\delta_{h t}$ represents other sources of household's income like nets transfers. The amount of other income $\delta_{t}$ in period t used for consumption depends on household's own crop income. If capital market works imperfectly, the sensibility of $\delta_{t}$ to $\pi_{t}$ depends on household's own stock of assets. The household's other income is supposed to depend as well on the crop income of its partners connected via marital arrangements. In particular, it is assumed that:

$\delta_{h t}=\alpha\left(w_{h t}\right)\left(\pi_{h t}-\mu_{h t}\right)+\sum \gamma_{k}\left(\pi_{h t}-\pi_{k t}\right)$

where $w_{h t}$ is household wealth at time t, $\mu_{h t}$ is household expected crop income at time $t, \pi_{k t}$ is the crop income at time $t$ of the kth potential transfer partner, and $\alpha$ and $\gamma_{k}$ measure the extent to which own wealth and transfer households, respectively, contribute to smoothing income, where $\alpha<0, \alpha^{7} \leq 0$, and $\gamma_{k} \leq 0$

If we assume that households have an infinite horizon and the stochastic income process is characterized by stationarity, changes in consumption for household $\mathrm{h}$, given Equations 1 and 2 are related to changes in its crop income:

$d C_{h}=[1+\alpha(w)] d \pi_{h}+\sum \gamma_{k}\left(1-\frac{d \pi_{k}}{d \pi_{h}}\right) d \pi_{h}$

where $\frac{d \pi_{k}}{d \pi_{h}}$ expresses the intertemporal relationship between the crop income of household $\mathrm{h}$ and the incomes of its transfer partners. In Equation 3, if credit markets work perfectly or all households are able to self-insure perfectly, then $\alpha=1$ and $\gamma_{k}=0$ and consumption does not change. If no household can save income and there are no risk-pooling arrangements via credit markets or familial contracts, then $\alpha=0$ and $\gamma_{k}=0$ and current consumption is then dependent solely on current crop income.

According to Rosenzweig and Stark (1989), the most difficult component to measure in Equation 3 is the covariation in incomes between the (potential) transfer partners and the farm household. Such information would require a survey that followed over time all households or individuals potentially engaged in risk pooling/income sharing. Rosenzweig and Stark (1989) suggest using the information on distance between the household's origin of the resident married women, based on the findings that distance is negatively related to the covariation in agricultural income. The basic equation estimated is then:

$\Delta C_{h}=\beta_{0}+\beta_{1} \Delta \pi_{h}+\beta_{2} I_{h}+\beta_{3} W_{h}+\beta_{4} M_{h}+\beta_{5} D+\varepsilon_{h}$

where $\Delta C_{h}$ and $\Delta \pi_{h}$ are consumption and profit variances, respectively, I is inherited wealth, $\mathrm{W}$ is the number of resident 
Table 1. Descriptive statistics (Means) (PNGT2 Data, 2004-2006).

\begin{tabular}{lccc}
\hline Variable & $\mathbf{2 0 0 4}$ & $\mathbf{2 0 0 5}$ & $\mathbf{2 0 0 6}$ \\
\hline Food Consumption (CFA) & 144992.1 & 157975.1 & 116768.1 \\
Farm profit (CFA) & 27408.72 & 9473.6 & 12543.24 \\
Inherited wealth (CFA) & 152896 & 112568.2 & 112704.6 \\
Number of migrants (Unit) & 0.366 & 0.969 & 0.88 \\
Number of married women (Unit) & 2.008 & 2.141 & 2.248 \\
Women married from same village (\%) & 0.250 & 0.270 & 0.270 \\
Women married from another village (\%) & 0.550 & 0.500 & 0.540 \\
Women married from anotherregion (\%) & 0.200 & 0.230 & 0.190 \\
\hline
\end{tabular}

married women, $M$ is the number of household migrants, $D$ is the mean distance between the sample household $h$ and the household's origin of the resident married women and $\varepsilon_{h}$ is the household-specific error term. The data do not allow to measure the distance between the origin and the residence of married women. The location of married women (from the same village, another village but same region, another region) was used as proxy of distance. For estimation, two modalities were recalled (from same village and from another village). Following this suggestion, it can test whether there is a payoff to increase the distance between the household of marital partners in terms of the enhanced ability of the household to smooth consumption via income sharing.

In specification (Equation 4), perfect intertemporal markets would imply all $\beta_{k}=0(\mathrm{k}=1$ to 5$)$. Alternatively, the absence of any mechanisms to transfer income either over time or contemporaneously across households implies that $\beta_{1}=1$, profit variance leads to consumption variance and $\beta_{l}=0, l=2, \ldots, 5$. With self-insurance and with spatial risk pooling associated with migrants and marriages, $\beta_{l}<0, l=2, \ldots, 5$.

\section{SAMPLING DESIGN AND DATA COLLECTION}

The article uses three rounds surveys conducted by Deuxième Programme National de Gestion des Terroirs (PNGT2) in 2004 to 2006. The three surveys are similar in the scope of the information collected, the sampling design and the coverage. The surveys are nationally representative and the sample selection uses random sampling. The number of households interviewed is 1980 for each year. For computing consumption and profit variance, we use information only on households observed three times.

The surveys collected information on household characteristics, consumption, production and migration. Table 1 reports descriptive statistics of the variables used in the analysis. The descriptive statistics show that households in rural Burkina Faso are facing volatility of food consumption and average consumption is estimated to CFA144992 in 2004 and failed to CFA 116768 in 2006. In 2005, its value was CFA 157975. Agricultural profit is also volatile and this result is not surprising for households facing rainfall high variability and fluctuation in agricultural prices like in Burkina Faso.

\footnotetext{
${ }^{1}$ CFA is the currency of the West AfricanEconomic and Monetary Union countries : Benin, Burkina Faso, Côte d'Ivoire, Guinea Bissau, Mali, Niger, Sénégal and Togo
}

Data indicate that farm profit does not explain all food consumption. The smaller value of farm profit is associated with the higher value of food consumption. This result shows that some factors like inherited wealth, migration and marital arrangements can explain food consumption. Food consumption growth is associated with inherited wealth decline from 2004 to 2005. Table 1 shows also that the number of migrants in the household seems to be stable, but increases if food consumption raised and farm profit (as proxy of agricultural income) failed, suggesting that migration can smooth food consumption in rural Burkina Faso.

It is apparent from Table 1 that the number of married women is stable across the three years. Each year, approximately the surveyed households report two married women. But it can be noted that agricultural profit is associated with little increasing number of married women suggesting risk pooling associated with marital arrangements.

Considering the origin of the resident married women, it was noted that half of married women are from another village and those who are from another region rise up to $23 \%$, suggesting that marital arrangements can be used for risk pooling and consumption smoothing in rural Burkina Faso.

\section{EMPIRICAL MODEL ESTIMATIONS AND RESULTS DISCUSSION}

Table 2 reports estimates obtained from Equation 4. Some unobserved household characteristics would affect both the independent variables and the dependent variable. For example, household with larger or better land would take more wives, migrate less often and have relatively lower income and consumption variance. So, fixed effects were assumed and Generalized Least Squares method was applied for estimation. The results reject the hypothesis of perfect intertemporal markets. Profit variance, distance, inherited wealth, and number of migrant contributes significantly to reduce the variability in household food consumption. In rural Burkina Faso, markets imperfection does not enable households to smooth their food consumption by reducing agricultural profit variability. Households have to rely on implicit contractual arrangements aimed at mitigating income risks and facilitating consumption smoothing. These results are consistent with those found by Rosenzweig and Stark (1989) for rural India and Hoogeveen et al. (2011) for rural Zimbabwe.

The hypothesis that farm profit equals to one or 0.85 for 
Table 2. Determinants of variability in food expenditures in farm households, 2004-2006 (GLS estimates) (PNGT2 Data, 20042006).

\begin{tabular}{lcc}
\hline Variable & Estimated coefficients & Standard errors \\
\hline Profit variance & $0.0877^{\star * *}$ & 0.0042 \\
Married women origin (same village as reference) & $-0.0141^{* * *}$ & 0.00316 \\
Inherited wealth & $-2.90 \mathrm{E}-08^{* * *}$ & $1.82 \mathrm{E}-09$ \\
Number of married women & $-1.124 \mathrm{E}-03^{\star * *}$ & $4.23 \mathrm{E}-04$ \\
Number of migrants & $-0.0039^{* *}$ & 0.0015 \\
Constant & $1.01 \mathrm{E}+10$ & $7.16 \mathrm{E}+08$ \\
$\mathrm{R}^{2}$ & 0.310 & - \\
$\mathrm{F}$ & 219.07 & - \\
\hline
\end{tabular}

***Significant at the $1 \%$ level ** Significant at the $5 \%$ level.

Rosenzweig and Stark (1989) cannot be accepted and agricultural profit variance leads to a marginal variability of food consumption. Thus, the hypothesis of absence of any mechanisms to transfer income either over time or across households was rejected. Facing environment characterized by market failures and farm profit variability, households use arrangements such as marital one. Distance between the origin households of the marital partners, inherited wealth and migration contributes significantly to smooth consumption by reducing the variability in household food consumption for given variability in farm profit. In this view, daughters might be considered part of a household's assets portfolio and could be cashed during times of adversity to smooth consumption. This result is consistent with those of Hoogeveen et al. (2011) in rural Zimbabwe. Households' number of migrants also serves as informal insurance that could help households to smooth their consumption.

The results suggest also that households have self insurance mechanisms to smooth their food consumption through inherited wealth that reduces significantly the impact of profit variance variability in household food consumption. Households develop also spatial risk pooling strategies associated with marriage and migration. The results indicate that both the number of married women and the distance between the origin households of the marital partners contribute statistically to reduce the variability in household food consumption by given variability in farm profit. The presence of household migrants reduces the impact of profit variability.

\section{Conclusion}

This article focuses on consumption smoothing strategies among rural households in Burkina Faso, a developing country with very limited formal institutions for income and consumption insurance. The results show that because formal insurance market does not work perfectly in rural Burkina Faso, households rely to informal arrangements to smooth their consumption. The results provide evidence suggesting that migration and marriage can contribute to a reduction in variability of consumption. Thus, migrants and daughters could be considered as assets that can be cashed to smooth consumption if adverse shock occurs. Our findings suggest that in Rural Burkina Faso, households rely on self-insurance to cope with consumption variability and develop spatial risk pooling associated with migrants and marriages as response to incomplete financial markets. In rural Burkina Faso because of markets failures, there are many implicit insurance mechanisms that households use to deal with adverse shocks on consumption.

\section{Conflict of interests}

The authors have not declared any conflict of interest.

\section{REFERENCES}

Alderman H, Paxson CH (1994). Do the Poor Insure? A Synthesis of the Literature on Risk and Consumption in Developing Countries, in Economics in a Changing World, by Bacha EL (Ed.). 3:48-78.

Antle JM (1987). Econometric Estimation of Producers' Risk Attitudes. Am. J. Agric. Econ. 69(3):509-522.

Attanasio OP, Pavoni N (2011). Risk Sharing in Private Information Models with Assets Accumulation: Explaining the Excess Smoothness of Consumption. Econometrica 79(4):1027-1068.

Benjamin D (1992). Household Composition, Labor Markets, and Labor Demand: Testing for Separation in Agricultural Household Models. Econometrica 60:287-322.

Binswanger H, Rosenzweig M (1993). Wealth, Weather Risk and the Composition and Profitability of Agricultural Investments. Econ. J. 103:56-78.

Bliss C, Stern N (1982). Palanpur: The Economy of an Indian Village. Oxford: Oxford University Press.

Blundell R, Pistaferri L, Preston I (2008). Consumption Inequality and Partial Insurance. Am. Econ. Rev. 98(5):1887-1921.

Bradford A (2013). Sharing the Risks and Rewards of Economic Migration. Univ. Chic. Law Rev. 80(1):29-57.

Ellis F (2000). The Determinants of Rural Livelihood Diversification in Developing Countries. J. Agric. Econ. 51(2):289-302.

Fafchamps M, Lund S (2003). Risk-Sharing Networks in Rural Philippines. J. Dev. Econ. 71(2):261-287.

Fafchamps M (1993). Sequential Labor Decisions under Uncertainty: An Estimable Household Model of West African Farmers. Econometrica 61:1173-1198 
Fafchamps M, Udry C, Czukas K (1998). Drought and Saving in West Africa: Are Livestock a Buffer Stock?. J. Dev. Econ. 55(2):273-305.

Gertler P, Gruber J (2002). Insuring Consumption against Illness. Am. Econ. Rev. 92(1):51-70.

Goldstein M (1999). Chop Time, No Friends: Intra household, and Individual Insurance Mechanisms in Southern Ghana. Photocopy, London School of Economics.

Grimard F (1997). Household Consumption Smoothing through Ethnic Ties: Evidence from Cote d'Ivoire. J. Dev. Econ. 53(2):391-422.

Hoogeveen J, Klaauw B, Lomwel G (2011). On the timing of Marriage, Cattle and Shocks. Econ. Dev. Cult. Change 60(1):121-154.

INSD (1998). Analyse des résultats de l'enquête prioritaire sur les conditions de vie des ménages, Institut National de la Statistique et de la Démographie, Ouagadougou, Burkina Faso.

Jalan J, Ravallion M (1999). Are the Poor Less Well Insured? Evidence on Vulnerability to Income Risk in Rural China. J. Dev. Econ. 58(1):61-81.

Kaplan G, Violente GL (2010). How much Consumption Insurance Beyond Self-Insurance? Am. Econ. J. : Macroeconomics 2(4):53-57.

Kazianga $\mathrm{H}$ (2006). Motives for Household Private Transfers in Burkina Faso. J. Dev. Econ. 79:73-117.

Kazianga H, Udry C (2006). Consumption Smoothing? Livestock, Insurance and Drought in Rural Burkina Faso. J. Dev. Econ. 79(2):413-446.

Kochar A (1999). Smoothing consumption by Smoothing Income: Hours-of-Work Responses to Idiosyncratic Agricultural Shocks in Rural India. Rev. Econ. Stat. 81(1):50-61.

Morduch J (1990). Risk, production and saving: theory and evidence from Indian households", unpublished manuscript

Morduch J (1995). Income Smoothing and Consumption Smoothing. J. Econ. Perspect. 9(3):103-114.

Park C (2006). Risk Pooling between Households and Risk-coping Measures in Developing Countries: Evidence from Rural Bangladesh. Econ. Dev. Cult. Change 54(2):423-457.

Paxson C (1993). Consumption and Income Seasonality in Thailand. J. Polit. Econ. 101(1):39-72.

Paxson CH (1992). Using Weather Variability to Estimate the Response of Saving to Transitory Income in Thailand. Am. Econ. Rev. 82(1):1533.

Rosenzweig MR, Wolpin KI (1993). Credit Market Constraints, Consumption Smoothing, and Accumulation of Durable Production Assets in Low-Income Countries: Investments in Bullocks in India. J. Polit. Econ. 101(2):223-244.

Rosenzweig MR, Stark O (1989). Consumption Smoothing, Migration and Marriage from Rural India. J. Polit. Econ. 97(4):905-926.

Savadogo K, Bambio Y, Combary O, Ouedraogo A, Tiemtoré A, Traoré A (2006). Les conditions de vie, les revenus et la pauvreté des ménages ruraux au Burkina Faso : résultats de l'enquête de base du PNGT 2.Deuxième Programme National de Gestion des Terroirs, Ouagadougou.
Townsend RM (1994). Risk and Insurance in Village India. Econometrica 62(3):539-591.

Townsend RM (1995). Consumption Insurance: An Evaluation of RiskBearing Systems in Low-Income Economies. J. Econ. Perspect. 9(3):83-102.

Udry C (1994). Risk and Insurance in Rural Credit Market: An Empirical Investigation in Northern Nigeria. Rev. Econ. Stud. 61(3):495-526.

Udry C (1995). Risk and Saving in Northern Nigeria. Am. Econ. Rev. 85(5):1287-1300.

Walker TS, Ryan JG (1990). Village and Household Economies in India's Semi-Arid Tropics. Baltimore, Md.: Johns Hopkins University Press.

Witoelar F (2005). Inter-household Allocations within Extended Households: Evidence from the Indonesia Family Life Survey. Center Discussion Paper no.912, Economic Growth Center, Yale University (May).

Yang D (2008). International Migration, Remittances and Household Investment: Evidence from Philippine Migrants Exchange Rate Shocks. Econ. J. 118(528):591-630.

Yang D (2011). Migrant Remittances. J. Econ. Perspect. 25(3):129151.

Yang D, Choi H (2007). Are Remittances Insurance? Evidence from Rainfall Shocks in the Philippines. World Bank Econ. Rev. 21(2):21948.

Zahonogo P (2002). La dynamique des activités non agricoles dans la stratégie de développement en milieu rural : évidences empiriques du Burkina.Thèse de Doctorat Unique, Université de Ouagadougou, Burkina Faso. 